\title{
Application of active films with natural extract for beef hamburger preservation
}

\author{
Maria Jeannine Bonilla Lagos $^{1^{*}}$ (D) Paulo José do Amaral Sobral ${ }^{1}$ \\ ${ }^{1}$ Faculdade de Zootecnia e Engenharia de Alimentos, Universidade de São Paulo (USP), Av. Duque de Caxias Norte, 225, 13635-900, \\ Pirassununga, SP, Brasil. E-mail: jeanninebonilla@usp.br. ${ }^{*}$ Corresponding author.
}

\begin{abstract}
Edible chitosan-based films, in pure form (CH100), or blended with gelatin (GEL50:CH50), with and without boldo extract (B) were prepared. The oxygen permeability of the films, as well as color changes and antioxidant and antimicrobial activities on beef hamburgers samples were evaluated. CH100+B film exhibited optimal oxygen barrier properties $\left(6.40 \pm 0.170 \mathrm{cc}-\mathrm{mL} /\left[\mathrm{m}^{2}\right.\right.$-day $\left.]\right)$, and this value was significantly increased in blended films (GEL50:CH50+B $=12.99 \pm 1.50 \mathrm{cc}-\mathrm{mL} /\left[\mathrm{m}^{2}-\right.$ day $]$ ) $(P<0.05)$. All films provoked color changes in hamburger samples during storage, and the samples covered with $\mathrm{CH100+B}$ film showed a lower brightness and a higher redness. All films effectively protected beef hamburger from lipid oxidation, and boldo extract incorporation in pure and blended films enabled significant protection, when compared to the control sample $(155.78 \pm 0.85 \mathrm{meq} O 2 / \mathrm{kg})(P<0.05)$. Finally, all films proved to be effective in microbial growth control, suggesting that these films are an effective alternative in improving food safety and quality of fresh meat.
\end{abstract}

Key words: beef hamburger, active-edible films, natural extract, antimicrobial activity, lipid oxidation, preservation.

Aplicação de filmes ativos com extrato natural para preservação de hambúrguer de carne bovina

RESUMO: Filmes comestiveis à base de quitosana, na forma pura (CH100), ou misturados com gelatina (GEL50:CH50), com e sem extrato de boldo (B), foram preparados. Avaliou-se a permeabilidade ao oxigênio dos filmes, assim como mudanças de cor e atividades antioxidantes $e$ antimicrobianas sob amostras de hambúrguer de carne bovina. Filmes de $\mathrm{CH} 100+B$ exibiram ótimas propriedades de barreira ao oxigênio $\left(6,40 \pm 0,170 \mathrm{cc}-\mathrm{mL} /\left[\mathrm{m}^{2}\right.\right.$-dia] $)$, e este valor foi significativamente aumentado em filmes mistos $\left(\mathrm{GEL} 50: \mathrm{CH} H 0+B=12,99 \pm 1,50 \mathrm{cc}\right.$-mL/[m ${ }^{2}$-dia $\left.]\right)$ $(P<0,05)$. Todos os filmes provocaram mudanças de cor nas amostras de hambúrgueres durante o armazenamento, apresentando as amostras cobertas com o filme CH100+B uma menor luminosidade e um maior vermelhidão. Todos os filmes protegeram efetivamente o hambúrguer de carne bovina da oxidação lipídica, e a incorporação do extrato de boldo em filmes puros e misturados possibilitou significativa proteção, quando comparada à amostra controle $(155,78 \pm 0,85 \mathrm{meq} O 2 / \mathrm{kg})(P<0,05)$. Finalmente, todos os filmes mostraram-se eficazes no controle do crescimento microbiano, sugerindo que estes filmes são uma alternativa eficaz para melhorar a segurança dos alimentos e a qualidade da carne fresca.

Palavras-chave: hambúrguer de carne bovina, filmes comestiveis ativos, extrato natural, atividade antimicrobiana, oxidação lipídica, preservação.

\section{INTRODUCTION}

Meat is recognized as one of the most perishable foods (DOULGERAKI et al., 2012). Fresh beef meat has an extremely short shelf life, ranging from three to five days when stored at $4^{\circ} \mathrm{C}$ (SIROCCHI et al., 2017), due to its high water content and chemical composition, which favor microbial growth to unacceptable levels, contributing significantly to meat spoilage (HAUTE et al., 2016; CASABURI et al., 2015; BONILLA et al., 2014). In addition, oxygen has a negative effect on meat quality (MOURE et al., 2001), where lipid oxidation, after microbial growth, is characterized as the primary cause of food decomposition (YUAN et al., 2016).

Application of active-edible films containing antioxidants and antimicrobials agents for food preservation represents a novel approach to improving the shelf life of food products(SIROCCHI etal.,2017). In this sense, diverse biopolymers have been employed for film production. Gelatin has been used for obtaining biodegradable films due to its edible and biodegradable nature, low cost and wide availability of sources (CLARKE et al., 2016). It retains optimal compatibility with other polymers, such as poly (vinyl alcohol) (ALVES et al., 2011), polysaccharides such as chitosan (BONILLA \& SOBRAL 2016), and others proteins such as sodium caseinate (BONILLA \& SOBRAL, 2017a). Conversely, chitosan has received significant consideration due to its biodegradability, biocompatibility, low cytotoxicity (DUTTA et al., 2009), and intrinsic antimicrobial activity, demonstrated in meat products (BONILLA et al., 2014; LEKJING, 2016; UPADHYAY et al., 2015). Chitosan has been approved by 
the United States Food and Drug Administration (FDA) as a Generally Recognized as Safe (GRAS) food additive (FOOD AND DRUG ADMINISTRATION, 2013).

According to HAUTE et al., (2016) and SIROCCHI et al., (2017), the demand for natural agents (e.g. essential oils or natural extracts) to replace synthetic additives (e.g. sorbate and benzoate) has increased in foodstuffs, due to their safety, biocompatibility, biodegradability and low toxicity. ATARÉS et al., (2010) informed that bioactive agents, with antioxidant activity, showed two different mechanisms of action: 1) oxygen barrier effect (reducing oxygen availability in the product) and 2) the particular antioxidant activity. Conversely, natural bioactive ingredients can present antibacterial properties against foodborne pathogens (such as Escherichia coli, Staphylococcus aureus, Listeria monocytogenes, and Salmonella typhimurium) (BURT, 2004).

Peumus boldus Molina (Chilean boldo) is a native tree from the central region of Chile. Phenolic constituents (primarily proanthocyanidins and flavonol glycosides), alkaloids, and essential oils are the main bioactive compounds of boldo leaf extracts, of which boldine is the main constituent. It retains GRAS status, conferred by the FDA, and is easily decomposed, making it environmentally friendly (GIRARDI et al., 2016).

BONILLA \& SOBRAL (2017b) studied the antioxidant and antimicrobial activity of boldo extract, among other extracts. Boldo extract at $1 \%$ was picking out for future studies due to the results obtained. Then, BONILLA \& SOBRAL (2016) developed active films based on gelatin-chitosan blends using boldo extract. The physical-chemical properties (suchasoptical, mechanical,microstructural and water vapor permeability, and antioxidant and antimicrobial activity) were determined, and the optimal antioxidant and antimicrobial properties of these films were reported. Previous results obtained in these different studies were the basis for choosing the formulations (gelatin50: chitosan50, boldo extract at $1 \%$ and glycerol at $0.2 \%$ ) used in the present study of application in food product.

Thus, the objective of the present research was to apply films based on pure chitosan (CH100) or blended with gelatin (GEL50:CH50), with and without boldo extract (B) on beef hamburger samples stored at $4^{\circ} \mathrm{C}$ up to 10 days, to study their preservation (food safety and the quality of fresh meat) in this conditions. Films were first evaluated regarding their oxygen permeability, and then color changes, lipid oxidation and microbial growth on beef hamburger samples were determined.

\section{MATERIALS AND METHODS}

\section{Materials}

Medium molecular weight chitosan $(\mathrm{CH})$ (MW: 190,000-310,000 Da, degree of deacetylation: 75-85\%; viscosity: 200-800 cps) was supplied by Sigma-Aldrich Química $^{\circledR}$ (São Paulo, SP, Brazil). Pigskin gelatin (GEL) (molecular weight $\sim 5.2 \times 10^{4} \mathrm{Da}$, bloom 260 , moisture content $=9.98 \%$ ) was supplied by GELNEX (Itá, SC, Brazil). Leaves of boldo (Peumus boldus Molina) were purchased from Florien, Insumos Farmacêuticos Ltda. (Piracicaba, SP, Brazil). Glycerol (PubChem CID: 753) and chemicals for lipid test (ethanol ( $\geq 99.5 \%$ ), chloroform, methanol, anhydrous sodium sulfate, acetic acid, hydrochloric acid, potassium iodide, sodium thiosulfate, and starch) were supplied by Labsynth $^{\circledR}$ (São Paulo, SP, Brazil). Petrifilm ${ }^{\text {TM }}$ Plates (S. aureus, total coliforms and aerobic microorganism) were supplied by $3 \mathrm{M}^{\mathrm{TM}}$ (Sumaré, SP, Brazil).

\section{Preparation of films}

Chitosan $(\mathrm{CH})$ and pigskin gelatin (GEL) solutions were prepared separately, according to BONILLA \& SOBRAL (2016). Chitosan (1\% w/w) was dispersed in an aqueous solution of glacial acetic acid $(1.0 \% \mathrm{v} / \mathrm{w})$. In parallel, gelatin ( $4 \mathrm{~g} \mathrm{GEL} / 100 \mathrm{~mL}$ of distilled water) was hydrated for $30 \mathrm{~min}$, and solubilized afterward in a thermostatic bath (Marconi ${ }^{\circledR}$ MA-184, Piracicaba, SP, Brazil $)$ at $55^{\circ} \mathrm{C}\left( \pm 0.5^{\circ} \mathrm{C}\right)$. Next, glycerol $(0.2 \%)$ was added in GEL solution. Boldo extract (B), at $1 \%$, was prepared according to BONILLA \& SOBRAL (2016). Film-forming solutions (FFS) were prepared mixing both solutions for obtained the following formulations: films based on pure (CH100) and blended (GEL50:CH50) biopolymers without extracts, and films based on pure $(\mathrm{CH} 100+\mathrm{B})$ and blended (GEL50:CH50+B) biopolymers with B extract. The pure gelatin (GEL100) film was only prepared for oxygen permeability determination. All films were prepared using a casting technique and dried at $30^{\circ} \mathrm{C}-60 \% \mathrm{RH}$ for about $24 \mathrm{~h}$, in a climate oven with controlled atmosphere (Marconi ${ }^{\circledR}$ MA 835/UR, Piracicaba, SP, Brazil). Next films were peeled off and conditioned for seven days at $25^{\circ} \mathrm{C}-53 \% \mathrm{RH}$ in chambers containing saturated solutions of $\mathrm{Mg}\left(\mathrm{NO}_{3}\right)_{2}$. Thickness of all films was around $80 \mu \mathrm{m}$, measured with a micrometer (Mitutoyo Mexicana S.A. de C.V., State of Mexico, Mexico) at six random positions.

\section{Oxygen permeability of the films}

The oxygen permeability (OP) test was carried out following the ASTMD3985-95 (1995), at $25^{\circ} \mathrm{C}-50 \%$ $\mathrm{RH}$, and using a MOCON OX-TRAN ${ }^{\circledR} 2 / 21$ (Mocon $^{\circledR}$, Minneapolis, USA) device. Films $\left(50 \mathrm{~cm}^{2}\right)$ were clamped 
in the diffusion chamber. Pure oxygen ( $99.9 \%$ purity) was introduced into the upper half of the sample chamber, while pure nitrogen ( $99.9 \%$ purity) was injected into the lower half, where an oxygen sensor was placed. Three replicates were carried out per formulation.

\section{Beef hamburger preparation}

The bovine meat (Longissimus dorsi) was obtained from the slaughterhouse at Universidade de São Paulo (USP), Pirassununga campus, and it was processed after four hours of slaughter deboning, to produce beef hamburger samples of six $\mathrm{cm}$ in diameter and $0.5 \mathrm{~mm}$ of thickness. Both surfaces (top and bottom) of the hamburger samples were coated with the different film formulation. No-coated (control) and coated samples were placed in foam trays (length: $10.5 \mathrm{~cm}$, width $8.5 \mathrm{~cm}$, height $1 \mathrm{~cm}$ ), wrapped with a commercial stretch plastic film (PVC) and subsequently stored in refrigerated conditions $\left(4^{\circ} \mathrm{C}\right)$, with light. Different trays with samples were prepared for analysis at $0,3,7$ and 10 days. Four analytical replicates were carried out per formulation.

\section{Color determination of beef hamburger samples.} Color measurements were analyzed using a MiniScan MSEZ 1049 (HunterlLab $^{\circledR}$, Reston, VA, USA) colorimeter, with a spectral range from 400 to $700 \mathrm{~nm}, \mathrm{D} 65$ (day light) lamp, angle of $10^{\circ}$ and a measuring cell with an opening of $30 \mathrm{~cm}$. The CIEL ab system measurements ( $\mathrm{L}^{*}$ for luminosity, and $\mathrm{a}^{*}$ and $\mathrm{b}^{*}$ for the color-opponent dimensions) were obtained from sample reflection spectra. For beef hamburger samples analysis, the PVC and prepared films on both surfaces (top and bottom) were removed, and two minutes later, the color changes were measured on hamburger surface. Three replicates were carried out per formulation.

\section{Lipid oxidation on beef hamburger samples.}

Beef lipid was extracted following the BLIGH \& DYER (1959) method. Beef hamburger samples $(30 \mathrm{~g})$ were homogenized in $210 \mathrm{~mL}$ of a chloroform: methanol:distilled water (60:120:30) mixture, using a rotorstator homogenizer (T25 digital ULTRA-TURRAX ${ }^{\circledR}$ ) at a speed of $10,000 \mathrm{rpm}$ for $1 \mathrm{~min}$, at $4^{\circ} \mathrm{C}$. The homogenate was diluted with $60 \mathrm{~mL}$ of chloroform and homogenized at $10,000 \mathrm{rpm}$ for 30 seconds. Then, $60 \mathrm{~mL}$ of distilled water was added, and the mixture was homogenized again for 30 seconds. The homogenate was centrifuged at $4,500 \mathrm{~g}$ for $10 \mathrm{~min}$, at $4^{\circ} \mathrm{C}$, and the supernatant was transferred into a separating flask. Chloroform phase was drained off into a $250 \mathrm{~mL}$ Erlenmeyer flask containing from $2-5 \mathrm{~g}$ of anhydrous sodium sulfate, shaken well and decanted into a round-bottom flask through Whatman No. 4 filter paper. Lastly, the solvent was evaporated by a drying and sterilization oven, at $100^{\circ} \mathrm{C}$. The extracted lipid was then subjected to peroxide value (PV) analysis. PV determination was performed according to the BRAZILIAN ANIMAL FEED COMPENDIUM (2013).Beef hamburger lipid (3 g) was dissolved in a 2:3v/v mixture of chloroform and acetic acid. Subsequently, an oversaturated KI solution $(0.5 \mathrm{~mL})$ was added. The mixture was stirred for $1 \mathrm{~min}$, followed by the addition of $30 \mathrm{~mL}$ of distilled water. Next, titration with sodium thiosulfate solution $(0.001 \mathrm{~N})$ was carried out, using starch as an indicator. Peroxide value was expressed as milliequivalents of peroxide index per kilogram of lipid. All analyses were performed in triplicate.

\section{Microbiological analyses on beef hamburger samples.}

Beef hamburger samples (10g) were aseptically obtained and homogenized in a stomacher with $90 \mathrm{~mL}$ of sterile buffered peptone water, for two min. Aliquots were serially diluted in buffered peptone water. Then $1 \mathrm{~mL}$ of each dilution was placed onto Petrifilm ${ }^{\mathrm{TM}}$ Plates, according to the following official methods: AOAC 2003.07 (2012) (S. aureus), AOAC 991.14 (2012) (total coliforms), and AOAC 990.12 (2012) (aerobic plate count). The plates were incubated at $37^{\circ} \mathrm{C}$ and the colonies formed were analyzed after 24 hours for $S$. aureus and total coliforms, and 48 hours for aerobic microorganisms. All analyses were performed in triplicate.

\section{Statistical analyses}

Analysis of variance (ANOVA) was applied using the Statgraphics ${ }^{\circledR}$ Plus 5.1 software (Manugistics Corp., Rockville, MD, USA). Effects of storage time and different packaging treatments in beef hamburger samples were studied. Multiple means comparisons were performed using the Fisher's Least Significant Difference (LSD) test, at 95\% level of confidence level. Additionally, standard error of the mean (SEM) calculation was based on Mean Square Error of ANOVA analysis.

\section{RESULTS AND DISCUSSION}

\section{Oxygen permeability of the films}

In figure 1, it can be observed that pure CH100 and GEL100 films displayed similar and rather low oxygen permeability $(\mathrm{OP})$ values $(9.73 \pm 2.10 \mathrm{cc}-\mathrm{mil} /$ $\left[\mathrm{m}^{2}\right.$ - day $]$ ) and $9.74 \pm 2.10 \mathrm{cc}$ - $\mathrm{mil} /\left[\mathrm{m}^{2}\right.$ - day $]$ respectively), in comparison to those reported by other authors (DI PIERRO et al. 2011, CASARIEGO et al. 2009) $(P>0.05)$. Unfortunately, the film based on blended biopolymers without extract (GEL50:CH50) exhibited a significant increment in these values $\left(16.7 \pm 2.10 \mathrm{cc}-\mathrm{mL} /\left[\mathrm{m}^{2}-\right.\right.$ day $\left.]\right)$, when compared to pure films $(\mathrm{P}<0.05)$. These results can be due to glycerol plasticizer incorporation in the blend films, not present in the pure chitosan films. Addition of 
glycerol made the films more susceptible to moisture, contributing to promote mass transfer processes due to the promotion of molecular mobility, and then showing lower barrier properties compared to pure films.

Conversely, the presence of $\mathrm{B}$ extract in the pure chitosan $(\mathrm{CH} 100+\mathrm{B})$ and blended (GEL50:CH50+B) films resulted in significant reduction of OP values $\left(6.40 \pm 2.10 \mathrm{cc}-\mathrm{mil} /\left[\mathrm{m}^{2}\right.\right.$ - day $]$ and $13.0 \pm 2.10 \mathrm{cc}-\mathrm{mil} /\left[\mathrm{m}^{2}\right.$ - day] respectively), when compared to the same formulations without extracts $(P<0.05)$. These results can be due to the polar chemical structure of the polyphenolic compounds in the extract, reducing the ability of the nonpolar oxygen molecules to condense, by increasing the tortuosity and making it more difficult for oxygen to diffuse through the films.

Similar results were reported by WANG ET AL. (2016), who studied the OP of flexible soy protein isolate films by incorporating chestnut bur extracts, and concluded that when the extract content in the film was increased, the OP values of the film decreased $(\mathrm{P}<0.05)$. TALÓN ET AL. (2017) studied the OP of films based on chitosan and starch containing tannic acid and thyme extracts and observed that extract addition improved the oxygen barrier property of the films, which is consistent with the development of a tighter more closed structure.

\section{Color determination}

The film formulation was the factor that retained the highest influence on color changes (Table 1). The color of hamburger samples showed initial values (day 0 ) of $37.5 \pm 0.150,18.6 \pm 0.200$, and $15.8 \pm 0.160$ regarding luminosity $\mathrm{L}^{*}, \mathrm{a}^{*}$, and $\mathrm{b}^{*}$ measurements, respectively.

Regarding the $\mathrm{L}^{*}$ parameter, up to 10 days of storage, all film formulations affected the beef hamburger color, enabling a slightly significant decrease in the luminosity of the hamburger samples covered with pure chitosan films with $(\mathrm{CH} 100+\mathrm{B}=29.8 \pm 0.150)$ and without $(\mathrm{CH} 100=32.0 \pm 0.150) \mathrm{B}$ extract added $(P<0.05)$, with respect to non-coated samples (control) and other films. No change was observed regarding storage time.

Regarding to the $\mathrm{a}^{*}$ parameter, up to 10 storage days and considering the redness of the hamburger samples, a significant increment on this value (more vivid color) was observed in hamburger samples covered with $\mathrm{CH} 100+\mathrm{B}$ film (22.0 \pm 0.200$)$, compared with other samples $(\mathrm{P}<0.05)$. These other hamburger samples, covered or not with films, showed a reduction in their values (brownish color development), observing the lowest value in sample covered with GEL50:CH50+B $(10.7 \pm 0.200)$ at 10 days of storage. According to BONILLA et al. 2014, this can be a result of

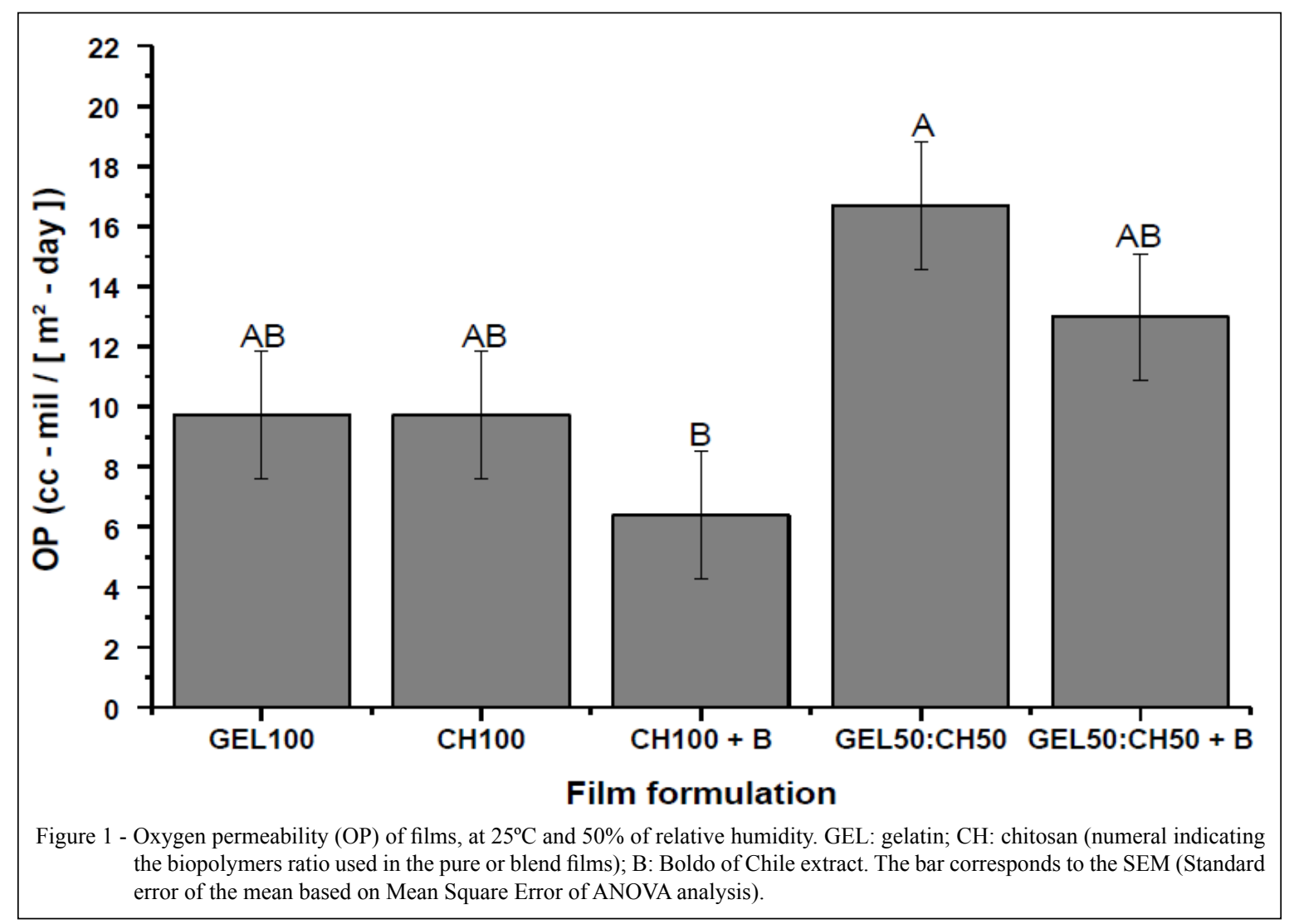

Ciência Rural, v.49, n.1, 2019. 
the conversion of myoglobin into metmyoglobin, due to the high oxygen pressure induced by the films, in which, in the case of $\mathrm{CH} 100+\mathrm{B}$ films, the process was slower.

Considering the $\mathrm{b}^{*}$ parameter (yellow-green color scale), neither the film formulations nor the storage days resulted in any significant differences in the color of all hamburger samples, varying between $14.1 \pm 0.160$ and $17.3 \pm 0.160$, for non-coated and coated samples with GEL50:CH50 film, respectively, up to 10 days of storage $(P>0.05)$. SIROCCHI et al. 2017, BONILLA et al. 2014, LEKJING, 2016 and GARRIDO et al. 2011 have reported color changes in beef or pork meat, coated with coatings or films for shelf life extension of these products.

VARGAS et al. (2016) added rosemary and pitanga extracts directly onto beef patties to evaluate color stability at $4^{\circ} \mathrm{C}$ during 4 days, and observed that pitanga extracts had a negative influence on meat color (redness and metmyoglobin formation), probably due to high chlorophyll content in extract, suggesting that this pigment affects myoglobin oxidation. LEKJING (2016) examined chitosan-based coatings, with or without clove oil, on cooked pork sausages, in refrigerated storage $\left(4 \pm 2^{\circ} \mathrm{C}\right)$ during 20 days. He reported that, during storage, the $\mathrm{L}^{*}, \mathrm{a}^{*}$, and $\mathrm{b}^{*}$ values of the control samples were not significantly altered by the treatment at any single storage time, probably due to chitosan and clove oil acting as preventive antioxidants on the meat product.

\section{Lipid oxidation}

Active films enriched with natural extracts are promising food preservation tools, due to the presence of bioactive compounds that have free radical scavenging actions, which can reduce the oxidation process, and, as a consequence, an extension of shelf life can be achieved (SIROCCHI et al. 2017). Meat has low oxidative stability and is very susceptible to rancidity during production and storage. Numerous studies have indicated that lipid oxidation in meat products may be controlled or minimized by using antioxidants (KANATT et al. 2008).

In the present research, it is remarkable that, at any control time (3, 7, and 10 days), all-edible films had a protective effect against lipid oxidation, when compared to the uncoated samples. This effect was more appreciable at the end of the storage period, when a greater advance of the process has occurred (Figure 2).

The initial peroxide value was $53.3 \pm 0.850 \mathrm{meq} / 1000 \mathrm{~g}$ of fat. At the end of the 10-day storage period, the uncovered samples exhibited a 3 -fold increase in the initial PV value $(156 \pm 0.850 \mathrm{meq} / 1000 \mathrm{~g}$ of fat $)$. At the same time, the covered samples showed PV values between $17.1 \pm 0.850$ and $108 \pm 0.850 \mathrm{meq} / 1000 \mathrm{~g}$ of fat, lower values when compared to the control sample. The addition of boldo extract in the films decreased the $\mathrm{PV}$ values $(\mathrm{CH} 100+\mathrm{B}=48.6 \pm 0.850 \mathrm{meq} / 1000 \mathrm{~g}$ of

Table 1 - CIELab color parameter values of refrigerated beef hamburger samples coated with the different films, without or with Boldo (B) extract.

\begin{tabular}{|c|c|c|c|c|}
\hline Film samples & Storage time (days) & $\mathrm{L}^{*}$ & $a^{*}$ & $b^{*}$ \\
\hline Non-coated & 0 & $37.5^{\mathrm{A}, \mathrm{a}}$ & $18.6^{\mathrm{B}, \mathrm{a}}$ & $15.8^{\text {A.a }}$ \\
\hline Non-coated & \multirow{5}{*}{3} & $39.5^{\mathrm{A}, \mathrm{a}}$ & $15.8^{\mathrm{B}, \mathrm{ab}}$ & $15.5^{\text {A.a }}$ \\
\hline CH100 & & $35.0^{\mathrm{BC}, \mathrm{a}}$ & $18.9^{\mathrm{AB}, \mathrm{ab}}$ & $18.9^{\text {A.a }}$ \\
\hline $\mathrm{CH} 100+\mathrm{B}$ & & $32.5^{\mathrm{B}, \mathrm{a}}$ & $20.5^{\mathrm{A}, \mathrm{ab}}$ & $15.5^{\text {A.a }}$ \\
\hline GEL50:CH50 & & $38.9^{\mathrm{A}, \mathrm{a}}$ & $15.9^{\mathrm{AB}, \mathrm{ab}}$ & $14.3^{\text {A.a }}$ \\
\hline GEL50:CH50+B & & $38.5^{\mathrm{AC}, \mathrm{a}}$ & $16.5^{\mathrm{B}, \mathrm{ab}}$ & $15.6^{\text {A.a }}$ \\
\hline Non-coated & \multirow{5}{*}{7} & $38.5^{\mathrm{A}, \mathrm{a}}$ & $14.5^{\mathrm{B}, \mathrm{ab}}$ & $14.4^{\text {A.a }}$ \\
\hline CH100 & & $33.6^{\mathrm{BC}, \mathrm{a}}$ & $14.2^{\mathrm{AB}, \mathrm{ab}}$ & $12.6^{\text {A.a }}$ \\
\hline $\mathrm{CH} 100+\mathrm{B}$ & & $33.5^{\mathrm{B}, \mathrm{a}}$ & $20.7^{\mathrm{A}, \mathrm{ab}}$ & $18.5^{\text {A.a }}$ \\
\hline GEL50:CH50 & & $40.9^{\mathrm{A}, \mathrm{a}}$ & $15.5^{\mathrm{AB}, \mathrm{ab}}$ & $18.0^{\text {A.a }}$ \\
\hline GEL50:CH50+B & & $34.4^{\mathrm{AC}, \mathrm{a}}$ & $12.1^{\mathrm{B}, \mathrm{ab}}$ & $13.9^{\text {A.a }}$ \\
\hline Non-coated & \multirow{6}{*}{10} & $41.2^{\mathrm{A}, \mathrm{a}}$ & $13.3^{\mathrm{B}, \mathrm{b}}$ & $14.1^{\text {A.a }}$ \\
\hline CH100 & & $32.0^{\mathrm{BC}, \mathrm{a}}$ & $12.4^{\mathrm{AB}, \mathrm{b}}$ & $16.4^{\text {A.a }}$ \\
\hline $\mathrm{CH} 100+\mathrm{B}$ & & $29.8^{\mathrm{B}, \mathrm{a}}$ & $22.0^{\mathrm{A}, \mathrm{b}}$ & $16.9^{\text {A.a }}$ \\
\hline GEL50:CH50 & & $38.0^{\mathrm{A}, \mathrm{a}}$ & $13.7^{\mathrm{AB}, \mathrm{b}}$ & $17.3^{\text {A.a }}$ \\
\hline GEL50:CH50+B & & $38.3^{\mathrm{AC}, \mathrm{a}}$ & $10.7^{\mathrm{B}, \mathrm{b}}$ & $14.9^{\text {A.a }}$ \\
\hline SEM $^{*}$ & & 0.150 & 0.200 & 0.160 \\
\hline
\end{tabular}

Means with the same superscript $\left({ }^{\mathrm{ABC}}\right)$ to be compared vertically different films and $\left({ }^{\text {abc }}\right)$ to be compared vertically different times in LSD test. GEL: gelatin; $\mathrm{CH}$ : chitosan (numeral indicating the biopolymers ratio used in the blend films); B: Boldo of Chile extract; Control= non-coated samples. "SEM: Standard error of the mean based on Mean Square Error of ANOVA analysis. 
fat and GEL50:CH50+B $=17.1 \pm 0.850 \mathrm{meq} / 1000 \mathrm{~g}$ of fat) when compared to the covered samples without extract, revealing the antioxidant chemical effect of the active compounds of the extract, and the lower oxygen permeability values of these films containing the extract.

YUAN ET AL. (2016) reported that the antioxidant capacity of chitosan might be due to the ability of residual free amino groups of the polysaccharide to react with free radicals forming stable macromolecular radicals and ammonium groups. Moreover, O'BRIEN et al. (2006) described that boldo leaves contain tannins, essential oils (mainly ascaridole and cineole), and flavonoids, of which catechin was recently reported to be the most abundant of the metabolites. Therefore, the mentioned compounds appear to contribute in great extent to the total antioxidant capacity of B extracts and infusions. LEKJING (2016) studied peroxide value in the lipid fraction in cooked pork sausages during 25 days of storage at $4^{\circ} \mathrm{C}$, and concluded that the best antioxidant effect was obtained with the combination of chitosan and clove oil, possibly since chitosan acts as a chelator of transition metal ions that initiate lipid peroxidation and start chain reactions.

\section{Microbial counts}

Besides lipid oxidation, spoilage of meat can be considered a result of the microbial activity of a wide variety of microorganisms, since meat nutrient composition, $\mathrm{pH}$ (5.5-6.5), and high moisture content enable the growth and survival of microorganisms (CASABURI et al. 2015). Numerous methods are available to control spoilage and thus extend the shelf life of meat, among which the use of natural antimicrobial agents, since it was reported that bacterial counts are suppressed in meat stored aerobically in the presence of these compounds (DOULGERAKI et al. 2012).

Figure 3 shows the effect of different films, containing or not boldo extract, on the growth and survival of total aerobic, total coliform, and $S$. aureus microorganisms.

The initial microbial load of total aerobic microorganisms was $3.30 \pm 0.900 \mathrm{Log} \mathrm{CFU} / \mathrm{g}$. At the end of the storage period (10 days), the chitosan-based films, with $(\mathrm{CH} 100+\mathrm{B})$ or without $(\mathrm{CH} 100)$ boldo extract added, maintained the same microbial load $(3.20 \pm 0.900 \mathrm{Log}$ $\mathrm{CFU} / \mathrm{g}$ and $4.00 \pm 0.900 \mathrm{Log} \mathrm{CFU} / \mathrm{g}$ respectively) as the initial day $(P>0.05)$, exhibiting significantly lower values than non-coated samples $(8.80 \pm 0.900 \mathrm{Log} \mathrm{CFU} / \mathrm{g})$. Also, the blended films (GEL50:CH50 $=5.30 \pm 0.900 \mathrm{Log} \mathrm{CFU/g}$ and GEL50:CH50+B $=6.40 \pm 0.900 \mathrm{Log}$ CFU/g) exhibited a reduction in growth microbial, with respect to the control

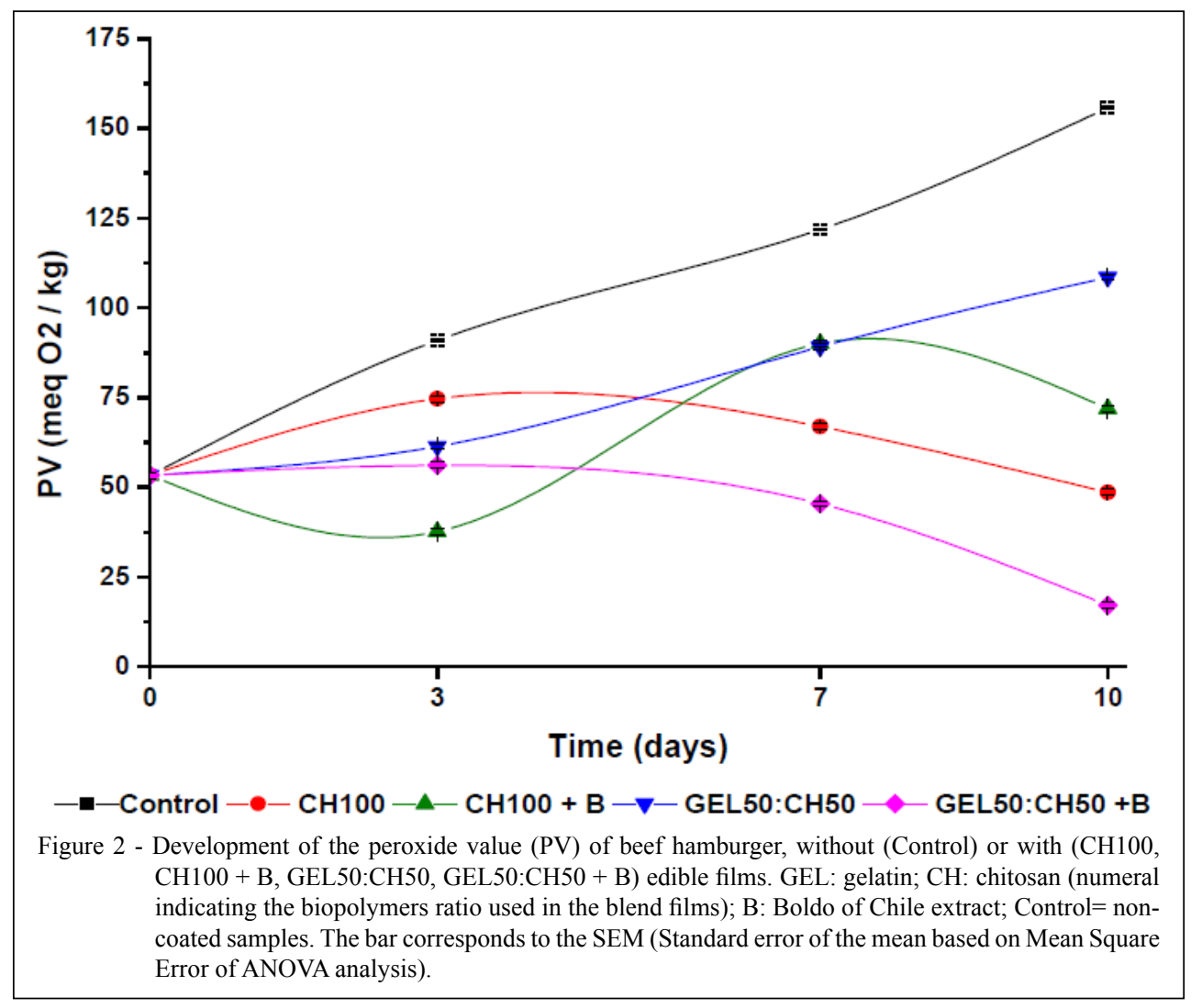

Ciência Rural, v.49, n.1, 2019. 
samples, but with significantly higher values than all CH100 films $(\mathrm{P}<0.05)$ (Figure 3).

Nevertheless, the initial microbial load of coliform microorganisms was $2.90 \pm 0.200 \mathrm{Log} \mathrm{CFU} / \mathrm{g}$. At 10 days of storage, all the films were effective in inhibiting the growth of coliforms on beef hamburgers samples when compared with the control sample $(8.10 \pm 0.200 \mathrm{Log} \mathrm{CFU} / \mathrm{g}) \quad(\mathrm{P}<0.05) \quad$ (Figure 3). As described previously, the chitosan-based films, with or without addition of boldo extract $(\mathrm{CH} 100+\mathrm{B}=$ $3.20 \pm 0.200 \mathrm{Log} \mathrm{CFU} / \mathrm{g}$ and $\mathrm{CH} 100=2.30 \pm 0.200 \mathrm{Log}$ $\mathrm{CFU} / \mathrm{g}$ ) exhibited lower values of microbial loads than blended films (GEL50:CH50 = 3.50 $\pm 0.200 \mathrm{Log}$ CFU/g and GEL50:CH50+B 4.80 $\pm 0.200 \log \mathrm{CFU} / \mathrm{g}$ ) at the end of the storage period $(\mathrm{P}>0.05)$. These results suggested that the antimicrobial effect of the films was directly associated with the chitosan concentration, of which antibacterial properties have been proven in previous studies with pork meat products (BONILLA et al. 2014).

Lastly, the initial microbial load of $S$. aureus microorganisms was $2.20 \pm 0.600 \mathrm{Log} \mathrm{CFU} / \mathrm{g}$. At 10 days of storage, differences in the antimicrobial effect of all films were described. The chitosan-based films $(\mathrm{CH} 100=$ $2.30 \pm 0.600 \mathrm{Log} \mathrm{CFU} / \mathrm{g}$ and $\mathrm{CH} 100+\mathrm{B}=2.30 \pm 0.600 \mathrm{Log}$ $\mathrm{CFU} / \mathrm{g}$ ) and blended films without extract (GEL50:CH50 $=2.30 \pm 0.600 \mathrm{Log} \mathrm{CFU} / \mathrm{g})$ maintained the initial microbiological load of $S$. aureus. Significant differences regarding GEL50:CH50+B films $\quad(3.20 \pm 0.600 \mathrm{Log}$ $\mathrm{CFU} / \mathrm{g}$ ) and non-coated beef hamburger samples $(4.00 \pm 0.600 \mathrm{Log} \mathrm{CFU} / \mathrm{g})$ were observed $(\mathrm{P}<0.05)$ (Figure $3)$. These results suggested that reducing the ratio of chitosan by $50 \%$, the antimicrobial activity of the blended films showed the same effectiveness, which was not improved by the addition of the B extract.

In general, all of the obtained results reflect that chitosan $(\mathrm{CH})$, alone or in the presence of B extract, retains remarkable antimicrobial activity on beef hamburgers, and the presence of gelatin (GEL) only contributed to improving preservation quality due to its antioxidant activity, with the incorporation of B extract.

JRIDI et al. (2018) studied the effect of active gelatin coated with henna (L. inermis) extract on beef meat quality during chilled storage $\left(4^{\circ} \mathrm{C}\right)$, and concluded that the combined coating (gelatin + extract) increased the shelf life of meat by decreasing the total and psychrophilic vial bacteria counts at the end of storage ( 8 days). And, XU et al. (2018) developed tapioca starch active nanocomposite films loaded with cellulose nanocrystal and with two grape pomace extracts (Cabernet Franc [red variety] and Viognier [white variety]) using a solvent casting method. They applied these films on ready-to-eat chicken meat and observed that films with grape pomace extracts exhibited a stronger inhibitory effect against $S$.
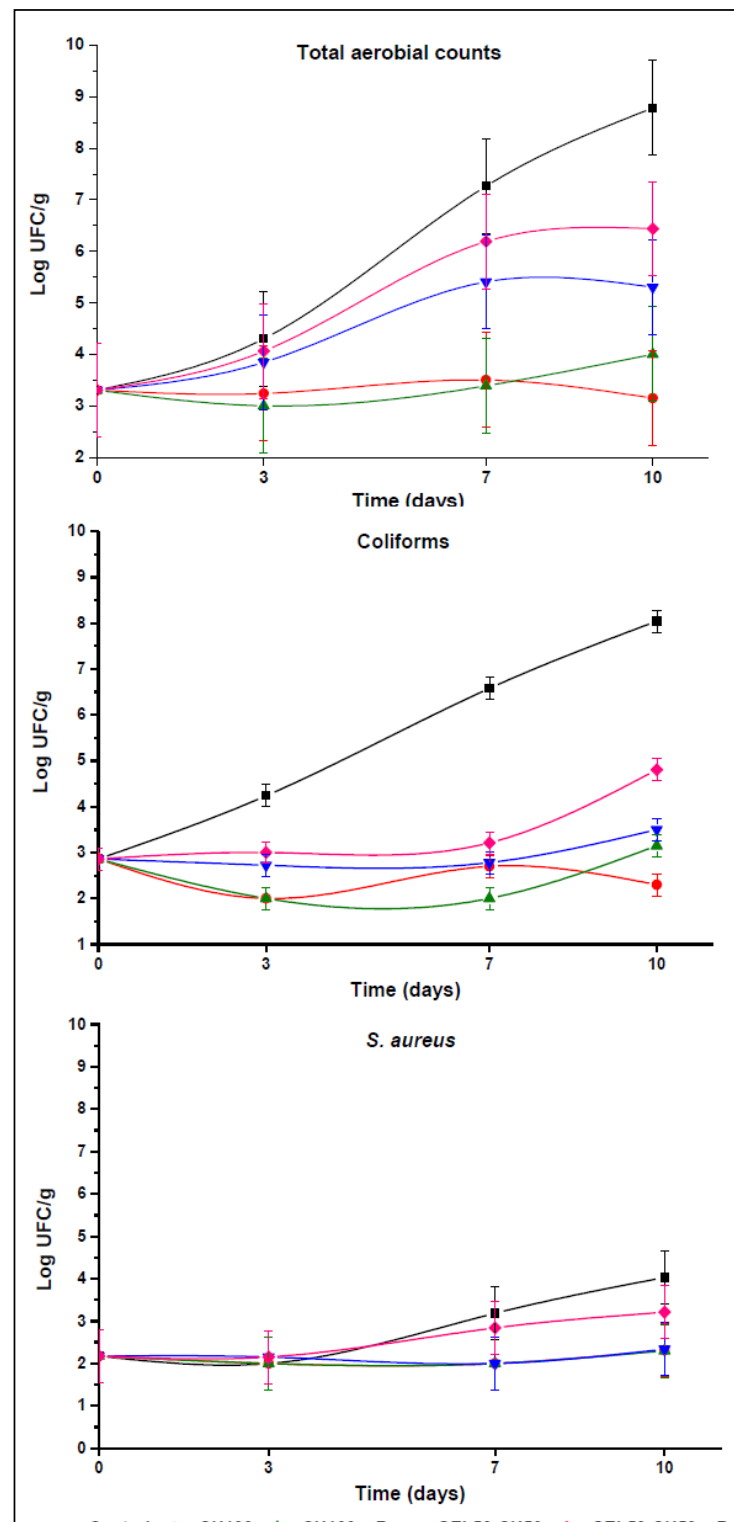

Figure 3 - Microbial counts of beef hamburger samples coated with edible films $(\mathrm{CH} 100, \mathrm{CH} 100+\mathrm{B}$, GEL50:CH50, GEL50:CH50 + B) or not (Control) as a function of storage time at $4{ }^{\circ} \mathrm{C}$ and $50 \%$ of relative humidity. GEL: gelatin; $\mathrm{CH}$ : chitosan (numeral indicating the biopolymers ratio used in the blend films); B: Boldo of Chile extract; Control= non-coated samples. The bar corresponds to the SEM (Standard error of the mean based on Mean Square Error of ANOVA analysis).

aureus (ATCC 29213) compared to L. monocytogenes (ATCC 7644). Further application of the films on readyto-eat chicken meats indicated that starch/cellulose nanocrystal/Viognier films were the most effective against $L$. monocytogenes inoculated on the meat samples during the 10 days at $4^{\circ} \mathrm{C}$. 


\section{CONCLUSION}

Pure chitosan (CH100) and pure gelatin (GEL100) films exhibited lower values of OP than blended films (GEL50:CH50), and B extract addition reduced these values significantly. All the films affected the surface color of beef hamburger samples, showing a slight decrease in luminosity and a significant increment of redness of the meat covered with $\mathrm{CH} 100+\mathrm{B}$ film at the end of the storage period. All edible films retained a protective effect against lipid oxidation and growth inhibition of microorganisms on beef hamburger samples at $4^{\circ} \mathrm{C}$. At any storage time, the PV values of meat samples coated with films containing B extract $(\mathrm{CH} 100+\mathrm{B}$ and GEL50:CH50+B) showed lower values when compared to the other samples (CH100, GEL50:CH50, and the control). Regarding microbiological analyses, chitosan films with $(\mathrm{CH} 100+\mathrm{B})$ or without $(\mathrm{CH} 100)$ boldo extract added were the most efficient in growth inhibition of total aerobic microorganisms. Also, GEL50:CH50+B blended films enabled a slight reduction in microbial load for coliform microorganisms, when compared to the other films. Regarding $S$. aureus microorganisms, differences in the antimicrobial effect were observed between pure $\mathrm{CH}$ and blended films (CH100; $\mathrm{CH} 100+\mathrm{B}$, GEL50:CH50 and GEL50:CH50+B) when compared to the control. Considering the obtained results, active-edible films can be used as an effective alternative packaging technology for improving food safety and fresh meat quality.

\section{ACKNOWLEDGEMENTS}

The authors acknowledge the financial support from the Fundação de Amparo à Pesquisa do Estado de São Paulo (FAPESP) (2013/07914-8), Postdoctoral fellowship of Jeannine Bonilla (2014/03288-8) and Conselho Nacional de de Desenvolvimento Científico e Tecnológico ( $\mathrm{CNPq})$ for the Research fellowship of Paulo J.A. Sobral (30.0799/2013-6).

\section{DECLARATION OF CONFLICTING INTERESTS}

We have no conflict of interest to declare.

\section{AUTHORS' CONTRIBUTIONS}

The authors contributed equally to the manuscript.

\section{REFERENCES}

ALVES, P. M. A. et al. Development of films based on blends of gelatin and poly(vinyl alcohol)cross linked with glutaraldehyde. Food Hydrocolloids, v.25, p.1751-1757, 2011. Available from: <https:// www.sciencedirect.com/science/article/pii/S0268005X11001044>. Accessed: Sept. 17, 2018. doi: 10.1016/j.foodhyd.2011.03.018.
ASSOCIATION OF OFFICIAL ANALYTICAL CHEMISTRY AOAC. Official Methods of Analysis 2003.07. $19^{\text {th }}$ ed. Washington, DC, 2012. Available from: <http://www.eoma.aoac.org/methods/info. asp?ID=5690 $>$. Accessed: Sept. 17, 2018.

ASSOCIATION OF OFFICIALANALYTICAL CHEMISTRY-AOAC. Official Methods of Analysis 991.14. 19 th $^{\text {th }}$ ed. Washington, DC, 2012. Available from: <http://eoma.aoac.org/methods/info.asp?ID=46949>. Accessed: Sept. 17, 2018.

ASSOCIATION OF OFFICIALANALYTICAL CHEMISTRY-AOAC. Official Methods of Analysis 990.12. 19 $9^{\text {th }}$ ed. Washington, DC, 2012. Available from: <http://eoma.aoac.org/methods/info.asp?ID=46762>. Accessed: Sept. 17, 2018.

ASTM D3985-95. Standard test method for oxygen gas transmission rate through plastic film and sheeting using a coulometric sensor. West Conshohocken, PA, 1995. Available from: $<$ https://www.astm.org/DATABASE.CART/HISTORICAL/D398595.htm>. Accessed: Sept. 17, 2018.

ATARÉS, L. et al. Characterization of sodium caseinate-based edible films incorporated with cinnamon or ginger essential oils. Journal of Food Engineering, v.100, p.678-687, 2010. Available from: $<$ https:// www.sciencedirect.com/science/article/abs/pii/S0260877410002657>. Accessed: Sept. 17, 2018. doi: 10.1016/j.jfoodeng.2010.05.018.

BLIGH, E. G.; DYER, W. J. A rapid method of total lipid extraction and purification. Canadian Journal of Biochemistry and Physiology, v.37, p.911-917, 1959. Available from: <http://www.nrcresearchpress.com/doi/ abs/10.1139/o59-099\#.XBIWIIV96Uk>. Accessed: Sept. 17, 2018.

BONILLA, J. et al. Effect of chitosan essential oil films on the storage-keeping quality of pork meat products. Food and Bioprocess Technology, v.7, p.2443-2450, 2014. Available from: <https://link. springer.com/article/10.1007/s11947-014-1329-3>. Accessed: Sept. 17, 2018. doi: 10.1007/s11947-014-1329-3.

BONILLA, J. et al. Recent patents on the application of bioactive compounds in food: a short review. Current Opinion in Food Science, v.5, p.1-7, 2015. Available from: $<$ https://www.sciencedirect.com/science/ article/abs/pii/S2214799315000818 $>$. Accessed: Sept. 17, 2018. doi: 10.1016/j.cofs.2015.05.012.

BONILLA, J.; SOBRAL, P. J.A. Investigation of the physicochemical, antimicrobial and antioxidant properties of gelatin-chitosan edible film mixed with plant ethanolic extracts. Food Bioscience, v.16, p.1725, 2016. Available from: <https://www.sciencedirect.com/science/ article/abs/pii/S2212429216300499>. Accessed: Sept. 17, 2018. doi: 10.1016/j.fbio.2016.07.003.

BONILLA, J.; SOBRAL, P. J. A. Antioxidant and physicochemical properties of blended films based on gelatin-sodium caseinate activated with natural extracts. Journal of Applied Polymer Science, v.134, 44467. Available from: <https://onlinelibrary.wiley.com/doi/abs/10.1002/ app.44467>. Accessed: Sept. 17, 2018. doi: 10.1002/app.44467.

BONILLA, J.; SOBRAL, P. J.A. Antioxidant and antimicrobial properties of ethanolic extracts of guarana, boldo, rosemary and cinnamon. Brazilian Journal of Food Technology, v20, e2016024, 2017b. Available from: $<$ http://www.scielo.br/scielo.php?script=sci_abstract\&pid=S198167232017000100432\&lng-pt\&nrm=iso\&tlng=en $>$. Accessed: Sept. 17, 2018. doi: 10.1590/1981-6723.2416.

BRAZILIAN ANIMAL FEED COMPENDIUM. Ed. Sindarações, Asbram. São Paulo, SP, 2013. 
BURT, S. Essential oils: their antibacterial properties and potential applications in foods - a review. International Journal of Food Microbiology, v.94,p. 223-253, 2004. Available from: <https://www. sciencedirect.com/science/article/pii/S0168160504001680>. Accessed: Sept. 17, 2018. doi: 10.1016/j.ijfoodmicro.2004.03.022.

CASABURI, A. et al. Bacterial populations and the volatilome associated to meat spoilage. Food Microbiology, v.45, p.83-102, 2015. Available from: $<$ https://www.sciencedirect.com/science/article/pii/S0740002014000276>. Accessed: Sept. 17, 2018. doi: 10.1016/j.fm.2014.02.002.

CASARIEGO, A. ET AL. Chitosan/clay films' properties as affected by biopolymer and clay micro/nanoparticles' concentrations. Food Hydrocolloids, v.23, p.1895-1902, 2009. Available from: <https:// www.sciencedirect.com/science/article/pii/S0268005X09000307>. Accessed: Sept. 17, 2018. doi: 10.1016/j.foodhyd.2009.02.007.

CLARKE, D. etal.Incorporation of commercially-derived antimicrobials into gelatin based films and assessment of their antimicrobial activity and impact on physical film properties. Food Control, v.64, p.202-211, 2016. Available from: $<\mathrm{https} / / / \mathrm{www} . s c i e n c e d i r e c t . c o m /$ science/article/ pii/S0956713515303509>. Accessed: Sept. 17, 2018. doi: 10.1016/j. foodcont.2015.12.037

DI PIERRO, P. ET AL. Chitosan/whey protein film as active coating to extend Ricotta cheese shelf-life. LWT - Food Science and Technology, v.44, p.2324-2327, 2011. Available from: <https:// www.sciencedirect.com/science/article/pii/S0023643810004081>. Accessed: Sept. 17, 2018. doi: 10.1016/j.lwt.2010.11.031.

DOULGERAKI, A. I. et al. Review: Spoilage microbiota associated to the storage of raw meat in different conditions. International Journal of Food Microbiology, v.157, p.130-141, 2012. Available from: <https://www.ncbi.nlm.nih.gov/pubmed/22682877>. Accessed: Sept. 17, 2018. doi: 10.1016 / j.ijfoodmicro.2012.05.020.

DUTTA, P. K. et al. Review: Perspectives for chitosan based antimicrobial films in food applications. Food Chemistry, v.114, p.1173-1182, 2009. Available from: $<$ https://www.sciencedirect.com/science/article/pii/ S0308814608013629?via\%3Dihub>. Accessed: Sept. 17, 2018. doi: 10.1016/j.foodchem.2008.11.047

GARRIDO, M. D. et al. Effect of two different red grape pomace extracts obtained under different extraction systems on meat quality of pork hamburgers. LWT - Food Science and Technology, v.44, p.2238-2243, 2011. Available from: $<$ https://www.sciencedirect.com/ science/article/pii/S0023643811002040>. Accessed: Sept. 17, 2018. doi: 10.1016/j.lwt.2011.07.003.

GIRARDI, N. S. et al. Microencapsulation of Peumus boldus oil by complex coacervation to provide peanut seeds protection against fungal pathogens. Industrial Crops and Products, v.92, p.93-101, 2016. Available from: $<$ https://www.sciencedirect.com/science/article/pii/S0926669016304940>. Accessed: Sept. 17, 2018. doi: 10.1016/j.indcrop.2016.07.045.

HAUTE, S. V. et al. The effect of cinnamon, oregano and thyme essential oils in marinade on the microbial shelf life of fish and meat products. Food Control, v.68, p.30-39, 2016. Available from: $<$ https://www.sciencedirect. com/science/article/pii/S0956713516301311>. Accessed: Sept. 17, 2018. doi: 10.1016/j.foodcont.2016.03.025.

JRIDI, M. et al. Effects of active gelatin coated with henna (L. inermis) extract on beef meat quality during chilled storage. Food Control, v.84, p.238-245, 2018. Available from: <https://www.sciencedirect. com/science/article/pii/S0956713517303936>. Accessed: Sept.. 17, 2018. doi: 10.1016/j.foodcont.2017.07.041.
KANATT, S. R. et al. Chitosan and mint mixture: A new preservative for meat and meat products. Food Chemistry, v.107, p.845-852, 2008. Available from: $<$ https://www.sciencedirect.com/science/article/ pii/S0308814607009181>. Accessed: Sept. 17, 2018. doi: 10.1016/j. foodchem.2007.08.088

LEKJING, S. A chitosan-based coating with or without clove oil extends the shelf life of cooked pork sausages in refrigerated storage. Meat Science, v.111, p.192-197, 2016. Available from: <https://www.sciencedirect.com science/article/abs/pii/S0309174015300991?via\%3Dihub>. Accessed: Sept. 17, 2018. doi: 10.1016/j.meatsci.2015.10.003.

MOURE,A. et al. Review: Natural antioxidants from residual sources. Food Chemistry, v.72, p.145-171, 2001. Available from: <https:// www.sciencedirect.com/science/article/pii/S0308814600002235>. Accessed: Sept. 17, 2018. doi: 10.1016/S0308-8146(00)00223-5.

O'BRIEN, P.etal. Boldineand its antioxidant orhealth-promoting properties. Chemico-Biological Interactions, v.159, p.1-17, 2006. Available from: $<$ https://www.sciencedirect.com/science/article/pii/S0009279705002206>. Accessed: Sept. 17, 2018. doi: 10.1016/j.cbi.2005.09.002.

SIROCCHI, V.etal.Effect of Rosmarinus officinalis L. essentialoil combined with different packaging conditions to extend the shelf life of refrigerated beef meat. Food Chemistry, v.221, p.1069-1076, 2017. Available from: $<$ https://www.sciencedirect.com/science/article/pii/S0308814616318921>. Accessed: Sept. 17, 2018. doi: 10.1016/j.foodchem.2016.11.054.

TALÓN, E. et al. Antioxidant edible films based on chitosan and starch containing polyphenols from thyme extracts. Carbohydrate Polymers, v.157, p.1153-1161, 2017. Available from: $<$ https://www.sciencedirect. com/science/article/pii/S0144861716312073>. Accessed: Sept. 17, 2018. doi: 10.1016/j.carbpol.2016.10.080.

UPADHYAY, A. et al. Control of Listeria monocytogenes on skinless frankfurters by coating with phytochemicals. LWT - Food Science and Technology, v.63(1), p.37-42, 2015. Available from: <https:// www.sciencedirect.com/science/article/pii/S0023643815002534>. Accessed: Sept. 17, 2018. doi: 10.1016/j.lwt.2015.03.100.

VARGAS, F. C. et al. Rosemary and pitanga aqueous leaf extracts on beef patties stability under cold storage. Brazilian Archives of Biology and Technology, v.59, e16160139, 2016. Available from: $<$ http://www.scielo.br/scielo.php?pid=S151689132016000100514\&script=sci_abstract $>$. Accessed: Sept. 17, 2018. doi: 10.1590/1678-4324-2016160139.

WANG, H. et al. Physical and antioxidant properties of flexible soy protein isolate films by incorporating chestnut (Castanea mollissima) bur extracts. LWT - Food Science and Technology, v.71, p.33-39, 2016. Available from: <https://www.sciencedirect.com/science/article/ pii/S002364381630161X>. Accessed: Sept. 17, 2018. doi: 10.1016/j. lwt.2016.03.025.

XU et al. Tapioca starch active nanocomposite films and their antimicrobial effectiveness on ready-to-eat chicken meat. Food Packaging and Shelf Life, v.16, p.86-9187, 2018. Available from: $<$ https://www.sciencedirect. com/science/article/abs/pii/S2214289417303691>. Accessed: Sept. 17, 2018. doi: 10.1016/j.fpsl.2018.02.006.

YUAN, G. et al. Review: Chitosan films and coatings containing essential oils: The antioxidant and antimicrobial activity, and application in food systems. Food Research International, v.89, p.117-128, 2016. Available from: <https://www.sciencedirect.com/science/article/pii/ S096399691630429X?via\%3Dihub>. Accessed: Sept. 17, 2018. doi: 10.1016/j.foodres.2016.10.004. 